\title{
Restoration of communities dominated by false hellebore
}

\author{
RACHEL COSGRIFF, VAL JO ANDERSON, AND STEPHEN MONSON
}

At the time of research, authors were Graduate Student and Professor, Botany and Range Science Department, Brigham Young University, Provo, Utah 84602 and Botanist, Shrub Sciences Laboratory, Rocky Mountain Research Station, USDA Forest Service, Provo, Utah 84606.

\section{Abstract}

False hellebore (Veratrum californicum Durand) is a native component of high-elevation, meadow-riparian areas of the mountain West that has increased due to historic heavy grazing. In 1991, a study was established in dense stands of false hellebore to evaluate mechanical and chemical control methods to reduce false hellebore and increase the abundance of the other native herbaceous species in these tall-forb communities. Four control methods consisting of the herbicide glyphosate (Nphenophonomethylglycine), mow, mowing in 2 consecutive years (remow), and tillage were used in 1991-1992. Each method was evaluated based on (1) reduction of false hellebore stem densities; (2) response of residual understory species; and (3) effectiveness of seeding a perennial grass and forb mixture to sustain initial treatment control. Stem density of false hellebore and nested frequency data for all species were collected in 1991, 1992, 1995, and 1999. The glyphosate treatment was effective in reducing false hellebore stem density which allowed for recovery of the remnant tall-forb community. The till treatment, while effectively reducing false hellebore stem density, also eliminated the other species in the community, leaving it open to invasive weeds. The mow and remow treatments did not reduce false hellebore stem density, but did allow for recovery of other components of the tall-forb community. Seeding following control treatments had no effect on false hellebore stem densities due to poor establishment. The mechanical treatments were generally more cumbersome in application and limited to gentle topography and welldrained sites without surface rocks. The application of herbicides is much easier and is adaptable to all types of terrain. The use of the herbicide glyphosate gave the best balance of false hellebore control and recovery of the tall-forb community.

Key Words: Veratrum californicum, mechanical control, chemical control, glyphosate, tilling, mountain meadows, wet meadows

Veratrum californicum Durand (commonly known as false hellebore, California hellebore, skunk cabbage, or corn lily) is a native tall forb of the Liliaceae family that grows in small clones in wet meadow-riparian areas of the mountain West. Heavy livestock grazing dating back to early settlement is assumed to have caused significant increases in number and size of false hellebore clones (Loft et al. 1987, Anderson and Thompson 1993).

Although false hellebore is an integral component of late seral communities and provides excellent ground cover, several management concerns are associated with existing stands. Selective grazing in wet meadow and riparian areas has reduced the vigor, density, production, and seed production of many desirable

Manuscript accepted 16 Nov. 03.

\section{Resumen}

El "False hellebore" (Veratrum californicum Durand) es un componente nativo de las áreas de praderas ribereñas de alta elevación de las montañas del oeste que se ha incrementado debido al uso histórico de apacentamiento fuerte. En 1991 se estableció un estudio en poblaciones densas de "False hellebore" para evaluar métodos de control mecánico y químico para reducir el "False hellebore" $\mathrm{e}$ incrementar la abundancia de otras especies herbáceas nativas en estas comunidades de hierbas altas. En 1991-1992 se usaron cuatro métodos de control consistentes de: herbicida glifosato ( $\mathrm{N}$-fenofonometilglicine), siega, siega por dos años consecutivos y labranza. Cada método se evaluó en base a: (1) reducción de las densidades de tallos de "False hellebore"; (2) respuesta de las especies residuales de la estrato inferior y (3) la efectividad de sembrar un zacate perenne y una mezcla de hierbas para sostener el tratamiento control inicial. Durante los años de 1991, 1992, 1995 y 1999 se colectaron datos de la densidad de tallos de "False hellebore" $y$ de datos anidados de frecuencia para todas las especies. El tratamiento de glifosato fue efectivo en reducir la densidad de tallos de "False hellebore" lo cual permitió la recuperación de la comunidad de hierbas altas remanente. El tratamiento de labranza, mientras fue efectivo para reducir la densidad de tallos del "False hellebore", también eliminó las otras especies de la comunidad, dejando abierto el espacio para las malezas invasivas. El tratamiento de siega y siega por dos años no redujeron la densidad de tallos de "False hellebore", pero permitieron la recuperación de otros componentes de la comunidad de hierbas altas. La siembra después de los tratamientos de control no tuvo efecto en las densidades de tallos de "False hellebore" debido al pobre establecimiento. Los tratamientos mecánicos generalmente fueron mas incomodos para aplicar y están limitados a sitios de topografía suave, bien drenadosy sin rocas en la superficie. La aplicación de herbicida es mucho más fácil y es adaptable a todo tipo de terreno. El uso del herbicida glifosato dio el mejor balance de control de "False hellebore" y recuperación de la comunidad de hierbas altas.

herbaceous species (Vallentine 1989). With decreases of those species, false hellebore tends to increase, filling in available space and suppressing more palatable species (Loft et al. 1986). Spencer and Thompson (1984) indicate that false hellebore can even invade aspen stands in response to over-grazing in Utah. An additional concern is the plant's teratogenic effects when injested by livestock during certain developmental periods of the fetus (Binns et al. 1963, Keeler 1973, Keeler et al. 1986).

To reduce the poison and/or teratogenic threats to livestock and facilitate recovery of desirable herbaceous species, land managers are seeking methods to control false hellebore. Techniques suggested for controlling undesirable vegetation include herbicides, flooding, irrigation, drying, disking, plowing, rotovating, burning, 
cutting, mowing, and grazing or a combination of these treatments (Vallentine 1989, Van der Valk and Pederson 1989). However, the success of such methods will generally be determined by composition of the seedbank at the site. In areas with few remnant species, seeding or transplanting may be necessary to insure the successful re-establishment of a desirable community.

Previous studies have shown effective control of false hellebore using herbicides (Anderson and Thompson 1993, Street et al. 1968). Some herbicides have required successive years of treatment to achieve control (Williams 1991, Williams and Kreps 1970). Williams and Cronin (1981) suggested that the removal of false hellebore could increase production of associated grasses, sedges, and rushes by as much as $1,500 \mathrm{~kg} \mathrm{ha}^{-1}$ annually.

In a non-replicated trial initiated by range conservation staff on a U.S. Forest Service district in Utah, 6 chemical and 3 mechanical treatments to control false hellebore were compared (Anderson and Thompson 1993). Herbicide effectiveness varied by product, but generally reduced false hellebore stem densities and allowed recovery of residual species. Tilling, mowing, and diskchaining were evaluated. Tilling resulted in the highest overall reduction $(87 \%)$ of hellebore, but that treatment encouraged invasion of undesirable species. They recommended reseeding as a potential means of suppressing the growth of undesirable species on tilled sites.

As a follow-up to the Forest Service trials (Anderson and Thompson 1993), this study was initiated to technically evaluate the most promising treatments for control of false hellebore and their effects on recovery of remnant members of wet meadow-riparian plant communities. Four treatments ( 3 mechanical and 1 herbicide) were tested in dense stands of false hellebore. The objectives of this study were to: 1) test the effectiveness of each treatment in reducing false hellebore stem density, 2) determine the effects of different treatments on the remnant members of the wet meadow-riparian community, and 3 ) determine the effectiveness of seeding as a means of suppressing re-establishment of false hellebore.

\section{Study Site}

The study was established in Spring Canyon of the Price Ranger District (Manti-Lasal National Forest), Sanpete County, Utah (N $\left.39^{\circ} 36^{\prime} \mathrm{W} 111^{\circ} 17^{\prime}\right)$. The

Table 1. Seed mixture used to seed split plots following control treatments in patches of false hellebore in Spring Canyon, Utah, 1991.

\begin{tabular}{lc}
\hline \hline Seeded Species & Seeding Rate \\
\hline Grasses & $\left(\mathrm{kg} \mathrm{ha}^{-1}\right)$ \\
Agropyron trachycaulum (Link) Malte & 2.24 \\
Bromus carinatus H. \& A. & 2.24 \\
Dactylis glomerata L. & 1.12 \\
Stipa lettermanii Vasey & 1.12 \\
& \\
Eorbs & \\
Osmorhiza occidentalis (Nutt.) Torr. & 0.56 \\
Geranium viscosissimum Fisch. \& Mey & 1.68 \\
Lupinus alpestris Rydb. & 1.12 \\
Lomatium triternatum (Pursh) Coult, \& Rose & 1.68 \\
Valeriana occidentalis Heller & 0.56 \\
Penstemon rydbergii A. Nels. & 0.56 \\
Medicago sativa L. & 1.12 \\
\hline
\end{tabular}

area is a mountain wet meadow at 2,880 $\mathrm{m}$, running along the base of a steep slope and subjected to deep snowdrifts annually. The soil is classified as a silty clay loam, 36 to $76 \mathrm{~cm}$ deep (Ellison 1954). Soil pH is approximately 6.3 and soil moisture varies from 40 to $15 \%$ between spring and late fall (Ellison 1954). Annual precipitation varies between $60-70 \mathrm{~cm}$, most of which occurs between November and May. The area is grazed by sheep from 1 July to 1 October, but historical grazing pressures were much higher. Dense patches of false hellebore occupy a high percentage of this drainage.

\section{Methods}

A baseline inventory of false hellebore stem density, nested frequency, and species richness in the patches along the drainage allowed for 3 uniform patches to be selected as blocks for the study design. In June of 1991, a block measuring 30 by $60 \mathrm{~m}$ was measured and divided into 10 plots $(6$ by $30 \mathrm{~m})$ from each patch. The study was arranged as a Generalized Randomized Complete Block Design (Steele and Torrie 1980). Five treatments were randomly assigned twice within each block, giving 2 replications per block. This allowed for testing treatment response differences between patches within the meadow.

The glyphosate treatment was applied in late June of 1991 (prior to false hellebore flowering) using a backpack sprayer at a rate of 1 liter ha ${ }^{-1}$. Because of a closed stand density and high leaf area index associated with the upper canopy of false hellebore, glyphosate could be applied directly to plots with little threat to the understory species. The mow treatments were applied in early June of 1991, with the remow plots receiving a second treatment in early June of 1992. The till treatment was first mowed in July of 1991, followed by tilling to $20 \mathrm{~cm}$ in October of 1991. Control plots were untreated.

Each block was split, half of which was seeded in October of 1991 with a mixture of perennial grasses and forbs (Table 1) using a John Deere Flex-Planter. Treatment response data were collected from $10,0.25 \mathrm{~m}^{2}$ quadrats located along a central transect line of each plot in August of 1992, 1995, and 1999. Exact placement of quadrats from year to year was not possible due to disruption of initial markers by sheep grazing and small mammal activity, therefore, quadrats were located independently along a central transect line for each year of data collection. Data collection included a count of the number of stems of false hellebore and assignment of a nested frequency score (BLM 1996) for each species found within each quadrat. These counts and scores were recorded and averaged by year, treatment, seeding, replication, and block. Species which occurred consistently (in at least $5 \%$ of the $0.25 \mathrm{~m}^{2}$ quadrats) were included in the data analysis. Stand height of false hellebore was estimated for each treatment and recorded with photographs.

To further define trends and responses, residual herbaceous species were classified according to seral position. Seral positions were assigned as early, mid, and late (Table 2). The average nested frequency of all species in each seral group were summed to obtain a cumulative nested frequency score for each seral group by treatment and year.

Analysis of Variance (ANOVA) was accomplished using the SAS (Littell et al. 1996) mixed-model procedure. The replications were assigned as random variables and the year, seeding, and treatments were assigned as fixed variables. Species rich- 
Table 2. Seral groupings of species found in at least $5 \%$ of the false hellebore study plots (Spring Canyon, Utah).

\begin{tabular}{|c|c|c|}
\hline \multicolumn{3}{|c|}{ Seral Groupings' } \\
\hline Early-Seral Species & Mid-Seral Species & Late-Seral Species \\
\hline Descurainia pinnata (Walter) Britt. & Viola purpurea Kellogg & Poa reflexa Vasey \& Scribn. \\
\hline Polygonum douglasii Greene & Thalictrum fendleri Engelm. ex Gray & Agropyron trachycaulum (Link) Malte \\
\hline Chenopodium album $\mathrm{L}$. & Stipa lettermanii Vasey & Delphinium occidentale (Wats.) Wats. \\
\hline Androsace septentrionalis $\mathrm{L}$. & Epilobium brachycarpum Presl & Osmorhiza occidentalis (Nutt.) Torr. \\
\hline Stellaria jamesiana Torr. & Hackelia floribunda (Lehm.) Johnston & Bromus carinatus $\mathrm{H}$. \& A. \\
\hline Madia glomerata Hook & Arabis holboellii Hornem. & Polemonium foliosissimum Gray \\
\hline Galium boreale $\mathrm{L}$. & Achillea millefolium $\mathrm{L}$. & $\begin{array}{l}\text { Cicuta maculata } \mathrm{L} . \\
\text { Rudbeckia occidentalis Nutt. } \\
\text { Helenium hoopesii Gray }\end{array}$ \\
\hline
\end{tabular}

Seral groupings were based on descriptions made by Ellison (1954).

ness for each treatment was based on the average number of species per $0.25 \mathrm{~m}^{2}$.

\section{Results and Discussion}

There was no significant effect due to block in this study. Patches were initially selected on the basis of their similarity. False hellebore and the other species in the community responded similarly to the treatments throughout the patches in the drainage that made up this experiment. The treatments can be categorized by the intensity of the disturbance caused to both the soil and density of false hellebore. The mow and remow treatments, while removing top growth in the year of treatment, had relatively little impact on existing plants and soil surfaces. The herbicide caused a greater level of disturbance by killing the majority of the false hellebore plants and hence opening resource niches. The tilling treatment caused the most severe disturbance eliminating the entire herbaceous community and mixing the top $15-20 \mathrm{~cm}$ of soil. The nature and level of treatment disturbance influenced the response of false hellebore as well as the residual community.

\section{Glyphosate}

The glyphosate treatment was effective in reducing stem density (Fig. 1) and abundance of false hellebore as reflected in nested frequency scores (Fig. 2). This herbicide treatment effectively reduced stem densities over $80 \%$, with little recovery after 9 years. These results are in harmony with previous studies that have shown effective control of false hellebore with herbicides. Street et al. (1968) found control of false hellebore was $80 \%$ effective using 2,4-D (2,4-dichlorophenoxy acetic acid) and $70 \%$ effective using 2,4,5$\mathrm{T}$ (2,4,5 -trichlorophenoxy) 3 years after spraying. Williams and Kreps (1970) reported similar results $(90 \%$ effective

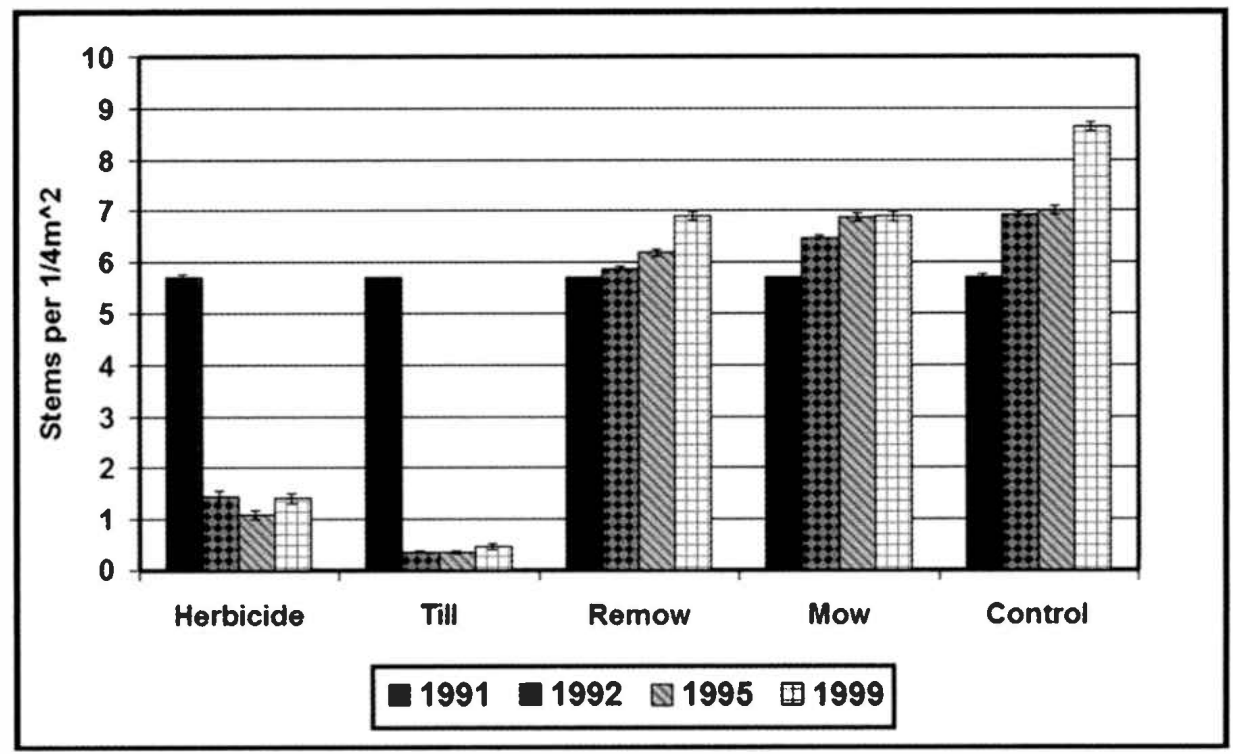

Fig. 1. Stem densities (average number of stems per $0.25 \mathrm{~m}^{2}$ ) of false hellebore for each tretment by year interaction $(\mathrm{P}<0.01)$. Treatments applied in 1991 to false hellebore in Spring Canyon, Utah.

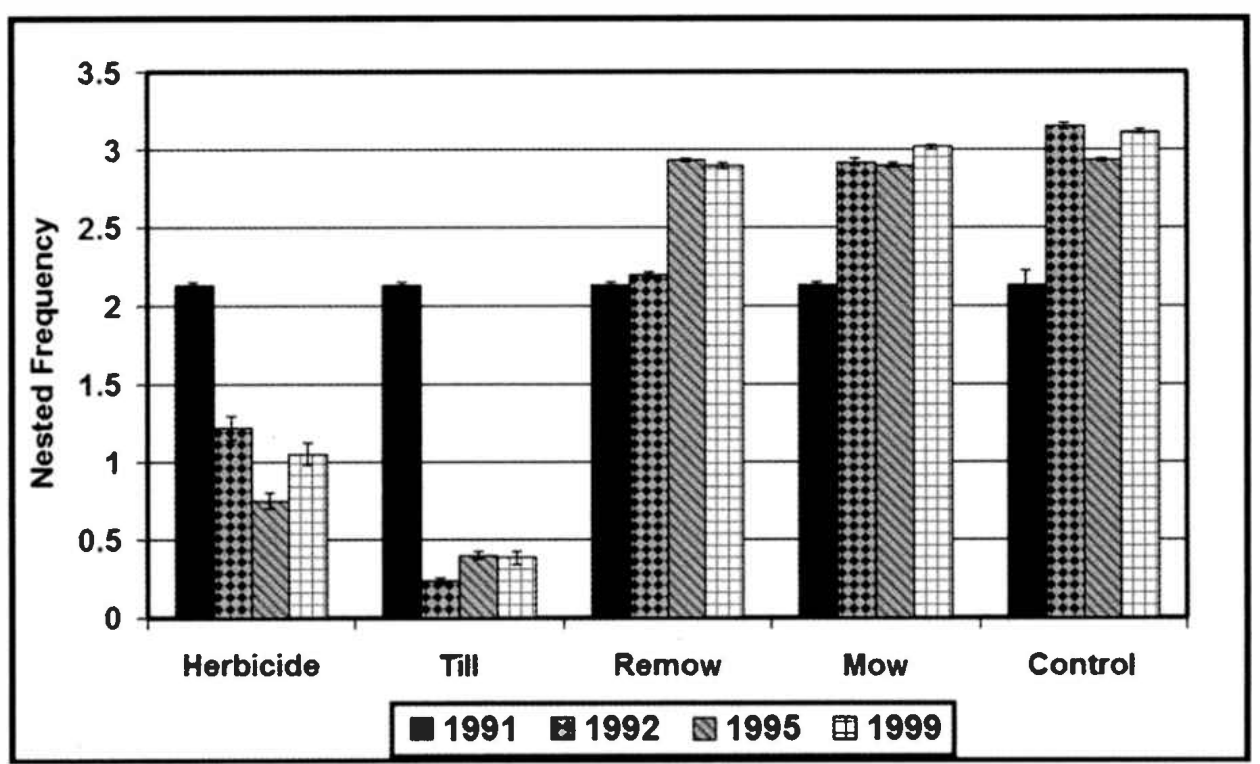

Fig. 2. Average nested frequency scores of false hellebore for each treatment by year interaction ( $P$ < 0.01). Treatments applied in 1991 to false hellebore in Spring Canyon, Utah. 


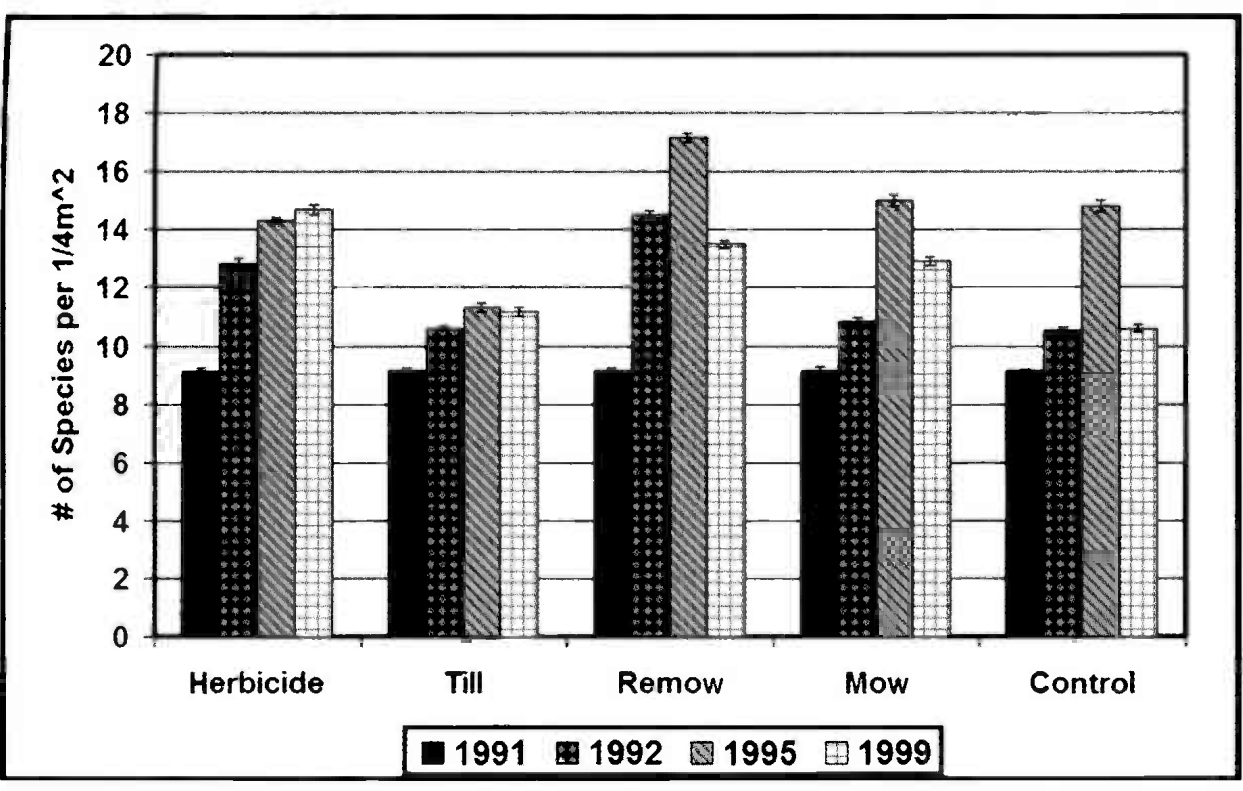

Fig 3. Average number of species per $0.25 \mathrm{~m}^{2}$ for each treatment by year interaction $(P<$ 0.01). Treatments applied in 1991 to false hellebore in Spring Canyon, Utah.

with 2,4-D and 70\% effective with 2,4,5T) after 2 years of treatment. Williams (1991) was successful at controlling false hellebore on plots treated with 2,4-D applied at a rate of 2 liters $\mathrm{ha}^{-1}$ in late spring for 2 consecutive years. After 10 years of treatment, he found no hellebore seedling establishment or lateral movement of the plants from control plots. Control remained at $100 \%$ after 20 years.

False hellebore plants surviving the glyphosate treatment were stunted in growth, rarely achieving $50 \%$ of the height or stem diameter of control plants. This effect continued throughout the study. It is not clear if a residual effect of the herbicide persisted or if competitive suppression from recovery of the tall forb community was responsible. Reduction in stem density became evident the year after treatment, since the plants had post treatment green tissues until frost dieback in the fall of 1991.

Tillman (1988) considered that vegetational dominants preferentially allocate resources to production of large leaves (increased photosynthetic activity) and tall stems (reducing competition for light). Possessing both advantages, false hellebore easily dominates disturbed wetmeadow communities. However, because of the high plant density and leaf area index of false hellebore, this species is an ideal candidate for herbicide control. The majority of the glyphosate was captured within the canopy of the plant, protecting the understory species from exposure to the herbicide. A significant increase in species richness occurred with the Utah. trol by the second year, but at the end of 8 years, the control had diminished to approximately $30 \%$. As with our herbicide treatment, all of the herbicides from their study were effective in opening the false hellebore canopy to the point of significant community expression of species otherwise suppressed.

In a multiple use setting, the intent of treatments is not to remove false hellebore completely from the community. It has historically been part of the diverse wet meadow-riparian community and is recognized for positive elements of wildlife habitat. Multiple herbicide treatments as described by Williams (1991) can completely control false hellebore, but the second year treatment would also kill much of the recovering tall forb community, resulting in grass domination (Williams and Kreps 1970, Williams and Cronin 1981) or weedy infestations.

\section{Tilling}

Similar to the report by Anderson and Thompson (1993), tilling was the most effective treatment in reducing false hellebore stem density. Tilling the soil to a depth of approximately $20 \mathrm{~cm}$ eliminated or severely weakened the roots of the plant, diminishing the possibility for the short-term recovery that was allowed by the mow and remow treatments.

Of all the treatments, tilling most effectively reduced false hellebore stem densities in the initial treatment. All stems were eliminated as part of the tilling treatment in 1991. By 1995, stem density was less than 0.5 stems per $0.25 \mathrm{~m}^{2}$, a reduction of

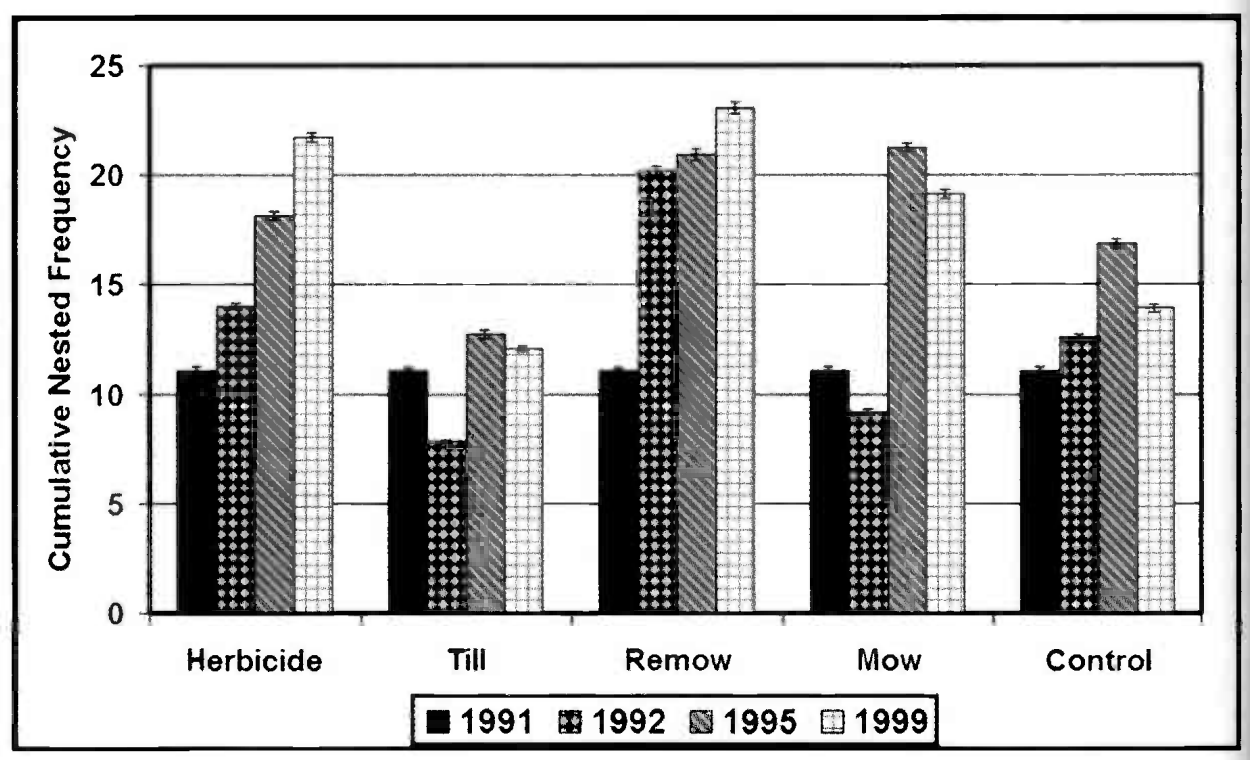

Fig 4. Cumulative nested frequency scores of late-seral species for each treatment by year interaction $(P<0.01)$. Treatments applied in 1991 to false hellebore in Spring Canyon, 


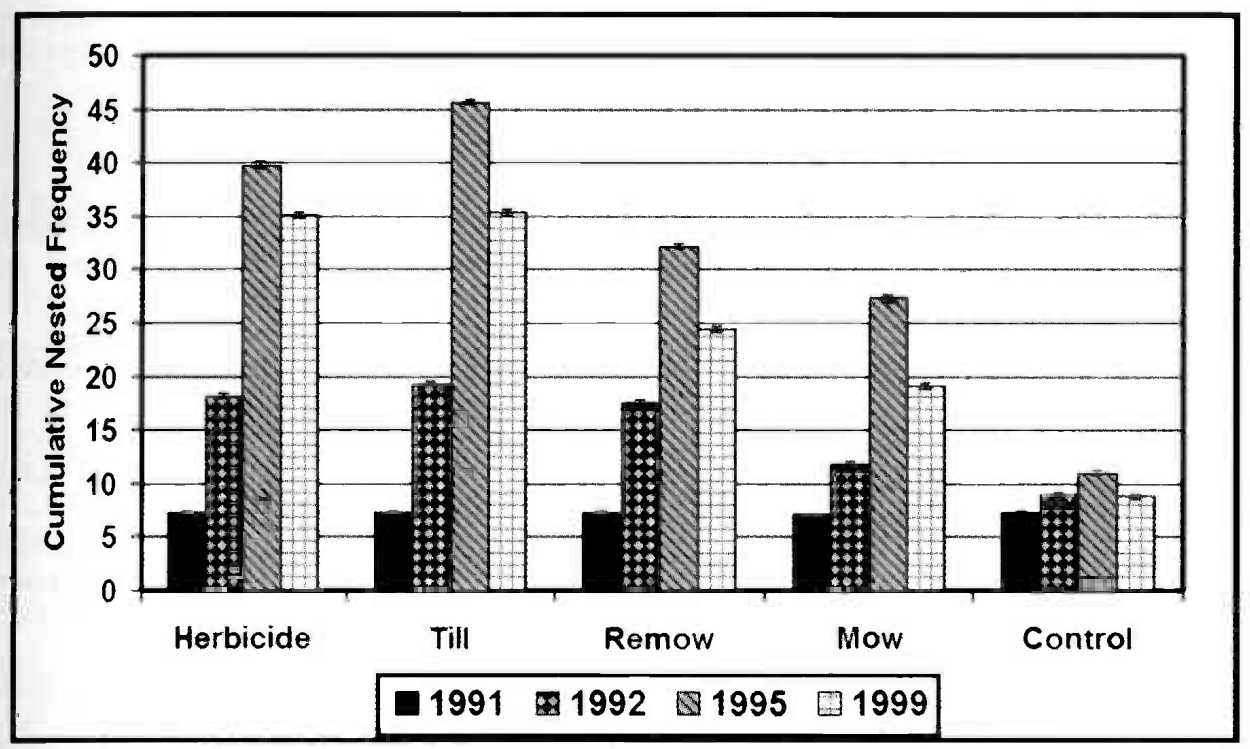

Fig 5. Cumulative nested frequency scores of early-seral species for each treatment by year interaction $(P<0.01)$. Treatments applied in 1991 to false hellebore in Spring Canyon, Utah. Seral groupings are listed in Table 2.

93\% (Fig. 1). The population demonstrated little recovery over time and averaged only 0.5 stems per $0.25 \mathrm{~m}^{2}$ in 1999 . However, tilling resulted in the lowest species richness of all treatments (Fig. 3). Tilling eliminated nearly all of the residual understory plants and recovery was slow. This left the area open and susceptible to invasion by weedy, early-seral species. Even after 9 years, the tilled treatment had a high amount of bare ground and was generally infested with weedy annuals, including thick patches of tarweed (Madia glomerata Hook.) (Fig. 6).

\section{Mow}

Mowing had the least effect of all treatments on removal of false hellebore. Although mowing removed all top growth the year of treatment, false hellebore stem density was not significantly different from the baseline in 1992, 1995, or 1999. Mowing did reduce false hellebore stem height in subsequent years. Even 9 years following treatment, plants in the mow treatment were $10-15 \mathrm{~cm}$ shorter than plants in the control treatment. While this study did nothing to explain this phenomenon, it is reasonable to speculate that the inability to photosynthesize during the

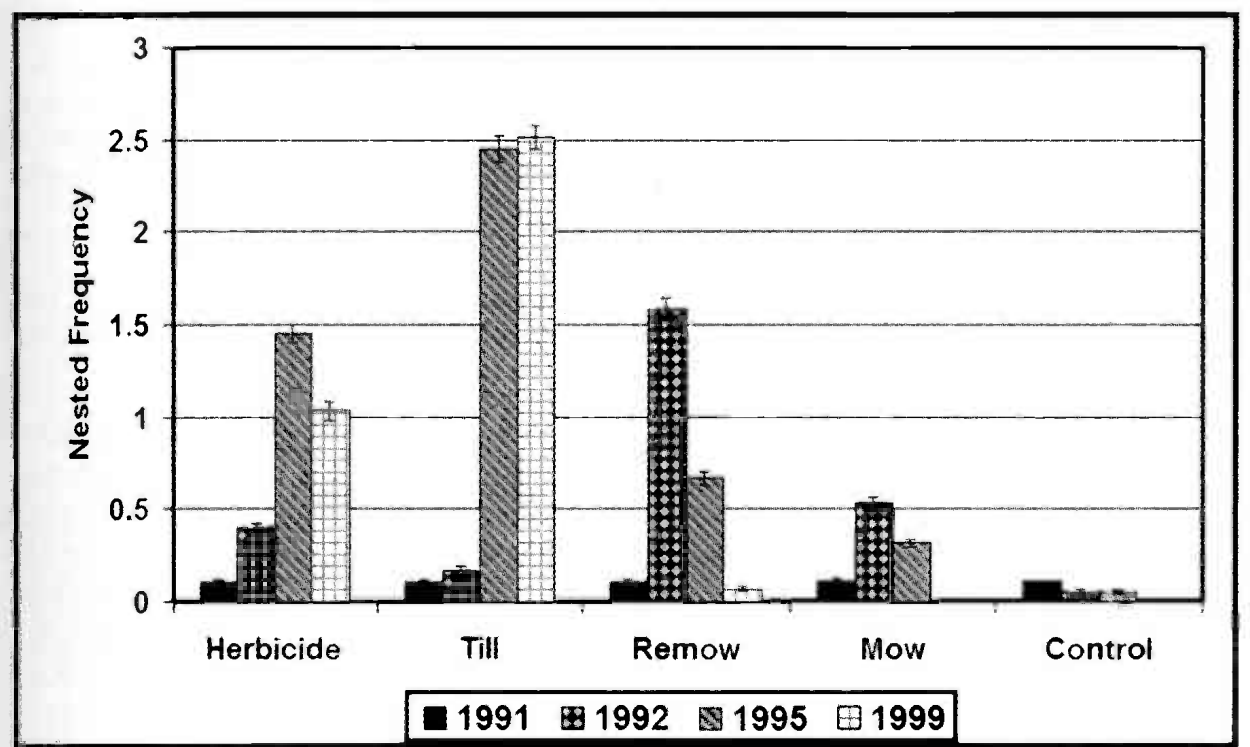

Fig 6. Average nested frequency scores of Madia glomerata for each treatment by year interaction $(P<0.01)$. Treatments applied in 1991 to false hellebore in Spring Canyon, Utah. year of treatment depleted resource storage found in the rhizome, limiting the plant's subsequent growth.

Mowing generally increased species richness over time (Fig. 3). Apparently, opening the canopy during the year of treatment encouraged growth of other species. By 1995, the mowed plots had increased abundance of late-seral species (Fig. 4). Although there was also an increase in early-seral species, it was less than that in all other treatments by 1999 (Fig. 5), indicating a low level of disruption by this treatment.

\section{Remow}

The remow treatment did not differ significantly from the mow treatment in the response of false hellebore and residual understory. A single defoliation treatment reported in the Anderson and Thompson study (1993) had caused such a decrease in plant height following treatment that they speculated a second defoliation in the subsequent year may have killed or substantially reduced false hellebore. However, in this study, the second mowing did not result in significantly fewer false hellebore stems (Fig. 1). Although all top growth was removed in the 2 consecutive years of treatment, post treatment stem densities were not significantly different from pretreatment values.

The remow treatment resulted in the greatest species richness in 1995, but species richness was similar to other treatments by 1999 (Fig. 3). Late-seral species responded positively to the remow treatment, while early-seral species responded similarly to the mow treatment.

\section{Seeding}

It was expected that seeding herbaceous native species following each treatment would decrease the recovery of false hellebore due to increased competition. However, seeding did not significantly decrease stem density or nested frequency of false hellebore. Although seeded species did germinate, establishment was low. Because an abundance of herbaceous species were already present in the community, competition was likely too great to allow for strong recruitment of seeded species. Generally, if an adequate seedbank exists before disturbance, the postdisturbance vegetation will closely resemble the pre-disturbance vegetation (van der Valk and Pederson 1989).

In the control plots, high density of false hellebore could explain low recruitment from the seeding, as false hellebore tends to monopolize resources early in the grow- 
ing season and put out a dense canopy quickly, limiting light available to understory species. The mow and remow treatments created an opening in the canopy of false hellebore during the first year following treatment. This likely allowed for the residual understory species to flourish with decreased competition for light. Thus, the seeded species had to compete with the pre-established community for newly-available resources. The herbicide treatment had a similar effect, though longer-lasting. Only the till treatment eliminated both false hellebore and most of the residual understory vegetation. It was anticipated that seeded species would be able to establish and compete with the invasive species, but seeding had no significant effect in controlling the invasion of early-seral species in this study.

\section{Conclusions}

The glyphosate treatment effectively controlled false hellebore over time with the least disturbance to the residual herbaceous community. This study showed 9 years of effective control following a single treatment, as well as an increase in desirable understory species. Advantages of using herbicides include: accessibility to areas where mechanical methods are impossible, a variety of application methods, rapid control, low labor, and selective removal of the target species. The use of herbicides is facilitated by false hellebore's large leaf-area index, which allows most of the herbicide to remain on the upper leaves and very little to drip down into the understory. However, non-selective herbicides (such as glyphosate) may cause damage to non-target species and must be applied within a narrow time interval, just before flowering (Vallentine 1989). The mowing treatments, while not effective in reducing false hellebore stem densities, were effective in allowing a resurgence of the remnant tall-forb community with very little weed invasion. The tilling treatment without significant reclamation, is not recommended because of the invasive weed potential.

\section{Literature Cited}

Anderson, V. and R. Thompson. 1993. Chemical and mechanical control of false hellebore (Veratrum californicum) in an alpine community. USDA For. Serv. Intermountain Res. Sta. Res. Paper INT-469. Ogden, Ut.

Binns, W., L. James, J. Shupe, and G. Everett. 1963. A congenital cyclopian-type malformation in lambs induced by maternal ingestion of a range plant, Veratrum californicum. Amer. J. Vet. Res. 24:1164-1 175.

BLM. 1996. Sampling vegetation attributes; Interagency technical reference. USDI, BLM, Nat. Appl. Resour. Sci. Center. BLM/RS/ST-96/002+1730.

Ellison, Lincoln. 1954. Subalpine vegetation of the Wasatch Plateau, Utah. Ecol. Monogr. 24:89-184.

Keeler, R. 1973. Teratogenic compounds of Veratrum californicum (Durand). Proc. Soc. Exp. Biol. and Med. 142:1287-1291.

Keeler, R., L. Stuart, and S. Young. 1986. When ewes ingest poisonous plants: The teratogenetic effects. Vet. Med. 81:449-454.
Littell, R.C., A. Milliken, W.W. Stroup, and R.D. Wolfinger. 1996. SAS system for Mixed Models. SAS Institute Inc. Cary, N.C.

Loft, E., J. Menke, and J. Kie. 1986. Interaction of cattle and deer on mountain rangeland. Calif. Agri. 40:6-9.

Loft, E., J. Menke, J. Kie, and R. Bertram. 1987. Influence of cattle stocking rate on the structural profile of deer hiding cover. J. Wildl. Manage. 51:655-664.

Spencer, S. and R. Thompson. 1984. Control of Veratrum californicum on the Manti-La Sal National Forest. Unpublished report on file at: Manti-La Sal National Forest, Price, Ut.

Steele, R.G.D. and J.H. Torrie. 1980. Principles and procedures of statistics: a biometrical approach. New York: McGraw-Hill, Inc. 633 pp.

Street, J., D. Bayer, and W. Brooks. 1968. Control of false hellebore (Veratrum californicum Durand). Western Soc. Weed Sci. 10:14-15.

Tilman, D. 1988. Plant strategies and the dynamic structure of plant communities. Princeton Univ. Press, Princeton, N.J.

Vallentine, J. F. 1989. Range development and improvements. Academic Press, Inc., San Diego, Calif.

van der Valk, A. G. and R. L. Pederson. 1989. Seed bank and the management and restoration of natural vegetation, pp. 329-346. In: Leck, M. A., V. T. Parker, and R. L. Simpson (eds.) Ecology of Soil Seed Banks. Academic Press, San Diego, Calif.

Williams, M. C. 1991. Twenty-year contol of California false-hellebore. Weed Tech. 5:40-42.

Williams, M. C. and E. Cronin. 1981. Ten year control of western false hellebore (Veratrum californicum). Weed Sci. 29:22-23.

Williams, M. C. and L. Kreps. 1970. Chemical control of western false hellebore. Weed Sci. 18:481-483. 